\title{
Social protection of foreign seasonal workers: from state to best practice
}

\author{
Christine Brickenstein ${ }^{1,2}$
}

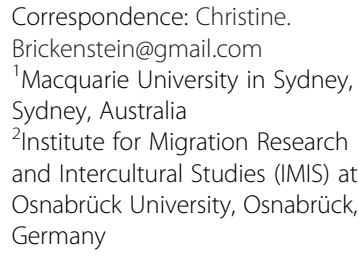

Correspondence: Christine. Brickenstein@gmail.com

${ }^{1}$ Macquarie University in Sydney, Sydney, Australia

${ }^{2}$ Institute for Migration Research and Intercultural Studies (IMIS) at Osnabrück University, Osnabrück, Germany

\begin{abstract}
The employment of foreign seasonal workers is often advocated for filling labour shortages, but at the same time criticised for being prone to exploiting migrants as cheap labour without granting them sufficient protection. The question of social protection rights of seasonal workers thus seems to be a crucial aspect in determining the success of seasonal worker schemes. This article analyses seasonal worker regulations in Australia, New Zealand, Germany and France. First, the level of protection international law provisions have set in place is examined. Second, the social security and work-related rights the four countries grant their seasonal workers are reviewed. Third, this article draws upon soft law, and legally non-binding or not widely ratified provisions in order to determine elements of a comprehensive set of social protection rights for seasonal workers. In conclusion, the practice of making social security contributions for seasonal workers mandatory without at the same time enabling them to benefit from these contributions is criticised. Therefore, it is recommended that a best practice model should provide for equal treatment with nationals in the area of work-related rights but make social security contributions either optional or shorten the qualifying periods, thus enabling workers to benefit from these services.
\end{abstract}

Keywords: Seasonal work; Labour migration; Agriculture; Social protection rights

\section{Springer}

\section{Background}

Temporary migration regimes have become increasingly popular in recent years, mostly due to a rising supply of and demand for low-skilled workers. In developed countries, the unmet demand for these workers has increased, predominantly in employment sectors unable to attract sufficient local workers due to unattractive work conditions, such as low wages, hard physical work or employment in remote areas. At the same time, an increasing number of low- or unskilled workers, are unable to find employment, and are looking for income opportunities abroad to raise their standard of living. Most affected by this trend are industries such as manufacturing, tourism, construction work and agriculture. This trend has caused several migrant-receiving countries to establish migration channels and programs, temporarily admitting lowskilled migrants in industries with severe labour needs. However, it has been criticised that the implementation of policies to protect migrant workers is not keeping pace with the growth of labour migration (International Labour Office, 2010: 71).

(c) 2015 Brickenstein; licensee Springer. This is an Open Access article distributed under the terms of the Creative Commons Attribution License (http://creativecommons.org/licenses/by/4.0), which permits unrestricted use, distribution, and reproduction in any medium, provided the original work is properly credited. 
Seasonal worker schemes need to find a balance between assigning too few rights to workers, making them vulnerable for exploitation, and creating an over protective system that makes the scheme too expensive for the employers. This balance stands in the wider context of the 'numbers versus rights' debate (Ruhs and Martin, 2008; Gibson et al., 2013). Therefore the most essential question that needs to be explored is: What level of rights for seasonal workers best meets the interests of the employer and worker? In that respect this article will mainly focus on social protection rights, distinguishing between work-related and social security rights.

Access to social security protection is important for migrants to reduce their vulnerability as migration is often linked to precarious employment (Lamarche, 2014: 32). As seasonal workers move between countries and labour markets, special provisions in the social security system should ensure that these migrants can adequately manage their risks (Sabates-Wheeler, 2009: 3; Avato et al., 2010: 455). The cost of social security rights is particularly relevant for seasonal workers, as their salary is often at the minimum wage, and thus every wage deduction must be considered carefully.

Generally, scholars agree that there is a need for a more coherent approach to social security coverage for migrant workers (Lamarche, 2014: 45). Marius Olivier criticised that the legal position of non-citizens in social security is generally low and that compliance with international and regional standards still has a long way to ensure that migrants and their families have adequate access for social protection rights (Olivier, 2011: 133). An innovative approach to offer targeted social protection to migrant workers and their families from a migrant sending country perspective has been implemented in Sri Lanka. The country set up an Overseas Workers Welfare Fund providing social insurance to migrants and families left behind in the case of death, disability, or the need to cover expenses to be repatriated to the home country (Rosario 2008).

Seasonal workers are temporary migrants who leave their home country in order to conduct seasonal work for several months per year. For the purpose of this study only the employment of agricultural seasonal workers was analysed. The agricultural sector was chosen because it provides employment for significantly more foreign workers than other industries with seasonal labour demand, but also because of the precarious work conditions characterising this sector.

Seasonal worker programmes are often also referred to as seasonal worker schemes and are administered by the relevant departments of the governments of the country of destination, for example the department of labour or immigration. Other relevant actors are the government departments in the migrant sending countries who are playing a major role in selecting and training workers as well as employers and relevant industry organizations in the country of destination.

Seasonal worker programmes are often advocated for having the potential of creating triple wins for the migrants, their countries of origin, and the destination countries (Ramasamy et al., 2008). These triple wins are created as circular seasonal migration can address labour shortages in agricultural sectors, provide migrants with income opportunities, and ideally have a development impact on the countries of origin.

European countries, such as France and Germany, have a long tradition of admitting foreign temporary workers through for example the guest worker systems established after the Second World War (Castles, 2006). Their experiences stand in contrast to countries that only recently established seasonal worker schemes, such as New Zealand 
and Australia. Whereas studies that compare seasonal worker programmes in the United States and Canada with those in Europe have been undertaken, no major comparative study has been conducted between France, Germany and the recent temporary foreign worker programmes of the Pacific (Martin, 2007). A significant number of research papers has analysed specific aspects of individual schemes, such as the development impact of the Recognised Seasonal Employer (RSE) scheme (Gibson et al., 2008; Ramasamy et al., 2008; Gibson and McKenzie, 2010; McKenzie and Gibson, 2010), the low take-up of the Australian pilot scheme (Hay and Howes, 2012), the protection of Pacific seasonal workers in Australia (MacDermott and Opeskin, 2010), and even the differences and similarities between the Australian and New Zealand scheme. But no major comparison has been conducted between Australia and New Zealand in contrast to France and Germany. While France and Germany have a longstanding history of foreign seasonal migration combined with a high intake of workers, Australia and New Zealand only recently established seasonal worker regulations with a comparatively lower intake.

This article analyses agricultural seasonal worker regulations in similar settings (France compared to Germany, and Australia compared to New Zealand) as well as in different settings (France and Germany compared to Australia and New Zealand) with the aim of identifying crucial social protection rights for foreign seasonal workers. The 2:2 case design allows the examination of programs according to the most similar system design as well as according to the most different system design (Rihoux and Ragin, 2008). This comparative research method outlines similarities and differences in social security rights across four countries with the aim of identifying crucial social security provisions that are of general importance for any seasonal worker regulation.

\section{Methods}

This article will first describe the functioning of the seasonal worker programmes in the four countries. Following, the rights of seasonal workers will be embedded in an international human rights framework, explaining which international binding legal obligations in relation to social security and work-related rights exist. Subsequent, the actual state practice and the question in how far these guaranteed rights are in compliance with the previously described international provisions will be analysed. In its third and final part this article examines legally non-binding or not widely ratified provisions in order to determine elements of a best practice set of rights for seasonal workers. For the purpose of this research an optimum level of rights is 3defined as providing foreign seasonal workers with adequate and customised social protection benefits, while at the same time minimising the costs for employer and worker. Comparing social protection rights of foreign seasonal workers across four countries provides the opportunity to not only identify similarities and differences, but also allows the identification of features of general relevance in relation to social protection rights. It will be argued that the current state practice of certain countries to make social security contributions mandatory for seasonal workers without enabling them to profit from these services formally complies with international standards but cannot be considered as best practice. 
An optimum level of social security rights consequently ensures equal treatment with nationals in the area of work-related rights. However, the contributions for social security benefits should be either made optional or the qualifying periods for seasonal workers should be shortened, enabling them to benefit from these services.

\section{Comparing seasonal worker programmes}

Seasonal worker schemes facilitate and regulate the employment of foreign seasonal workers. This article only focuses on employment in the agricultural sector. Most of these workers are employed in labour-intensive areas such as fruit, vegetable and horticulture or viticulture commodities (Martin, 2003: 20). Their everyday work ranges from harvesting crops to pruning and similar tasks.

Whereas seasonal worker schemes in Australia and New Zealand share many similarities, they differ significantly from the regulations in Germany and France. Most seasonal workers in Germany and France are Polish nationals (the second and third largest groups in France are workers from Tunisia and Morocco), in contrast to Australia and New Zealand where the majority of foreign seasonal workers (excluding backpackers) are Pacific Islanders. However workers from East Timor are employed in trial sectors in Broome, Western Australia and under the New Zealand scheme workers from selected countries in Asia have been admitted to the RSE programme under the condition that they have a pre-existing relationship with the employer in question. While in Germany and France foreign seasonal workers are taxed as domestic residents, special tax codes were introduced in New Zealand and Australia.

The recruitment process in all four countries is based on bilateral agreements in Germany and France (De Lary, 2004; Okolski, 2004), Inter-Agency Understandings in New Zealand and Memoranda of Understanding in Australia. Even though the majority of all workers were recruited from countries that have signed an agreement with the relevant host country, employers in New Zealand are allowed to recruit from any of the Pacific Island Forum countries.

The first bilateral agreements in Germany were signed in 1990, but foreign seasonal workers were already employed on an informal basis in the years before. Compared to their European counterparts, the seasonal worker regulations in Australia and New Zealand were only recently enacted. In New Zealand the Recognised Seasonal Employer programme was introduced in April 2007 (Maclellan, 2008: 2) and Australia introduced the Pacific Seasonal Worker Pilot Scheme (PSWPS) in August 2008 for a four-year trial period, which became the permanent Seasonal Worker Programme in July 2012. Seasonal labour migration from the Pacific to New Zealand was common already from the 1950s onwards. Initially this was not formally managed until in the 1970s formal schemes were enacted which terminated in 2002 (for more information on New Zealand's earlier work permit schemes see (Appleyard and Stahl, 1995)).

The recruitment process in all four countries is characterised by several similarities. In general before an employer can request a foreign seasonal worker, certain requirements must be fulfilled. First, a labour market test must prove that not enough domestic workers can be recruited to fill the labour shortage. Then an employer can apply for permission to recruit workers and request them either by name or anonymous. The recruitment of workers and the regulation of the scheme are mostly administered by the relevant ministries, for example the ministry for labour/employment or the ministry of immigration. To 
work in Australia or New Zealand workers must then undergo a health test, which is also mandatory for workers in France and Germany who are third country nationals and recruited from outside the European Union (EU). Typically the visa is subject to certain conditions, such as binding the worker to one single employer and imposing an obligation to leave the host country after termination of the work contract. However, while in New Zealand and Australia employers must arrange and pay upfront for workers' international travel arrangements (half of which they are allowed to recoup from the workers), in France and Germany workers have to pay and organise all travel and transportation by themselves.

Seasonal worker regulations are based on several premises. The most basic assumption is that migration matches the supply and demand for migrant labour. Migration programmes assume that well-managed migration is beneficial for all stakeholders, these being the migrant-sending countries, the migrant-receiving countries and the migrants themselves. Despite these shared objectives it is important to note that countries may emphasise certain objectives more than other. While seasonal worker regulations in Germany and France are strongly employer driven, the Australian and New Zealand schemes pursue twin objectives: fulfilling development goals and increasing labour supply, with Australia placing a slightly stronger emphasis on the development component and New Zealand on the labour supply.

The average duration a seasonal worker spends in the host country ranges from one or two months in Germany to six to nine months in the other case countries. Germany employs slightly below 300,000 foreign seasonal workers, by far the largest number especially when compared to Australia, where only 2,500 visas were made available under the Pacific Seasonal Worker Pilot Scheme (PSWPS), out of which only 1,623 were used until April 2012. Under the new permanent scheme, which was enacted in July 2012, more than 10,450 visas were made available for the duration of four years. The number of seasonal workers under the Recognised Seasonal Employer scheme in New Zealand increased from 2,800 in the first season in $2007 / 2008^{1}$ to 6,200 in 2009/2010 and to 9,000 in 2014 (Bennett and Woodhouse, 2014). The number of workers in France was around 15,000 on average; however the numbers dropped in France and Germany due to the 2004 EU enlargement round with Polish workers no longer being counted as foreign workers. In France and Germany official recruitment and the issuance of work permits is currently only necessary for third-country nationals as workers from all other Eastern European countries enjoy freedom of movement as citizens of EU member states.

Figure 1 displays in more detail the differences in the number of admissions of foreign seasonal workers in agriculture from 1990 onwards. As outlined above the schemes in Australia and New Zealand were enacted only recently, which explains the lack of data for earlier time periods.

\section{Rights of seasonal workers}

In this section the different sets of rights will be introduced. As such the main focus lies on the question of what kind of legally binding rights and obligations are created by international law provisions. After having examined international provisions this section then proceeds in analysing the actual state practice researching in how far states comply with these provisions or whether significant deviation takes place. 


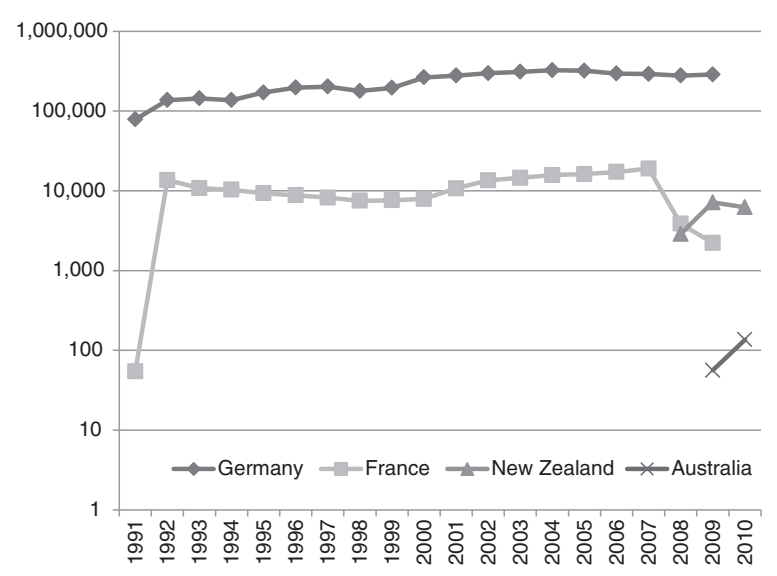

Figure 1 Number of admissions of seasonal workers in Germany, France, New Zealand and Australia from 1990 to 2010. Sources: (Becker and Heller, 2002; Bundesagentur für Arbeit, 2010; Deutsches Bundesamt für Migration und Flüchtlinge 2010; European Migration Network, 2010; Evalue Research, 2010; Evans, 2010; Plewa, 2010; Reed et al., 2010; New Zealand Department of Labour 2011).

For the purpose of this analysis two categories of social protection rights are analysed: work-related rights and social security rights. The examination of social security rights is important because they are often controversial. While it can be argued that seasonal worker programs are not intended for long-term employment-thus making unemployment and retirement benefits redundant - the experience in European countries demonstrates that some workers are involved in these schemes for up to 20 years. The long-term participants of these schemes should not only be covered by adequate social security rights but also have an interest in avoiding financial contributions for services they are unable to access. The category of work-related rights focusses on the right to choose one's employer as well as on the right to unionise. The examination of these two rights is crucial because the visa for most foreign seasonal workers ties them to one employer, increasing their vulnerability to abusive employment conditions. It is vital to analyse whether that risk is reasonable and adequate. Unions are able to support workers in difficult situations, educate them about their rights, negotiate employment conditions, act as mediators between workers and employers and are consequently an important stakeholder in protecting the rights of seasonal workers and ensuring their overall wellbeing.

\section{Human rights framework}

Before analysing specific rights in detail it is first of all crucial to identify the general human rights framework these rights are embedded in.

The most relevant international convention in this context is the United Nations International Convention on the Protection of the Rights of All Migrant Workers and Members of Their Families (ICRMW) which is concerned with the protection of migrant workers and families and makes explicit reference to seasonal workers. However, the convention was not ratified by most migrant-receiving countries including the four case countries. Generally the low ratification rate was explained with the fact that the convention was too ambitious and detailed and in some instances even contradicted national law (Ryszard Cholewinski et al., 2009: 12,17).

Further, several ILO conventions make explicit reference to migrant workers: The Convention concerning Migration for Employment (ILO Convention No. 97) was 
adopted after the Second World War and was widely ratified. However the Convention concerning Migrants in Abusive Conditions and the Promotion of Equality of Opportunity and Treatment of Migrant Workers (ILO Convention No. 143) was adopted in the aftermath of the oil crisis in the 1970s and countries were reluctant to ratify it as the convention focuses on the need to report undocumented migration (Ryszard Cholewinski et al., 2009: 7). Both conventions guaranteed the very important right of temporary migrants to equal treatment with national workers.

Right to equality of treatment:

The right to non-discrimination relates to the fact that seasonal workers are often subject to a different set of rights as they are not nationals of the host country. Equality of treatment is the most general and also most important set of rights for seasonal workers. It acts as an umbrella function that also influences other sets of rights, for example seasonal workers aspire to be treated equal to nationals in regard to access to emergency health services and also in terms of remuneration. The International Labour Organization (ILO) has been the first international organization that focused on migrant workers' rights by emphasising the need for equality of treatment between national and foreign workers (Lamarche, 2014: 9).

Several international law provisions regulate when discrimination on the basis of nationality is allowed or prohibited. Most international treaties, such as the International Covenant on Civil and Political Rights (ICCPR) and the International Covenant on Economic, Social and Cultural Rights (ICESCR) have established a general right of migrants to non-discrimination. Interestingly the ICCPR on the one hand specifically prohibits discrimination of ICCPR rights on the basis of nationality, but on the other hand permits discrimination in other areas, such as concerning the freedom of movement of irregular migrants and the restriction of political rights, such as the right to vote (Weissbrodt, 2008: 189).

Even though the intention of various international law instruments to promote the right to equal treatment of migrants is clearly visible, its implementation as will be shown below is less successful, as many instruments have either not specified the right or even explicitly excluded discrimination in relation to nationality from their provisions.

Table 1 summarises the ratification rate of the main human rights instruments in the four case countries.

\section{Work-related rights}

Work-related rights cover a wide range of issues, such as employment security, wages, labour inspections, equal treatment, forced labour, freedom of association and collective bargaining. However only two aspects of work-related rights will be analysed in this article: the right to change the employer, which is closely connected to the right of freedom

Table 1 Ratification of the main human rights instruments

\begin{tabular}{|c|c|c|c|c|c|}
\hline & ILO No.97, 1952 & ICCPR, 1976 & ICESCR, 1976 & ILO No. 143, 1978 & ICRMW, 2003 \\
\hline Australia & -二-二- & Ratified in 1980 & Ratified in 1975 & 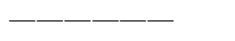 & \\
\hline New Zealand & Ratified in 1950 & Ratified in 1978 & Ratified in 1978 & & \\
\hline Germany & Ratified in 1959 & Ratified in 1973 & Ratified in 1973 & & \\
\hline France & Ratified in 1954 & Ratified in 1980 & Ratified in 1980 & & \\
\hline
\end{tabular}


of movement, and the right to unionise. These rights have been chosen as they both have the potential to make the migrant worker less vulnerable to exploitation.

One of the most crucial restrictions of work-related rights is the tying of the working visa to one employer, restricting the right to change the employer (Anderson, 2008: 201). Employers are interested in recruiting seasonal workers who are obliged to work only for them in order to compensate for the costs that are caused by the recruitment process (money, time, bureaucratic effort), but it can be argued that this is justified only for the first couple of months until the costs of the recruitment process are paid off. Scholars have supported the view that this constraint should always be combined with a an escape clause against abusive behaviour by the employer (Carens, 2008: 431). Furthermore, the limitation to one employer also results in a restriction of freedom of movement in the host country as the worker is consequently not free to choose her or his own place of residency.

Additionally, it is often argued that foreign seasonal workers should be permitted to join and actively participate in unions in order to be less vulnerable and thus to be able to bargain for equal and fair working conditions. Both of these rights are vital and connected to each other. Workers might be afraid to join and actively participate in unions because they fear they might lose their job and thus also their residence permits.

In that respect the ICCPR constitutes the most relevant international law instrument. It guarantees the right for all (including migrant) workers to join and participate in union activities. The right to unionise is further provided by the Collective Bargaining Convention (ILO Convention No. 98), the Freedom of Association and Protection of the Right to Organise Convention (ILO Convention No. 87), the ICRMW as well as the Universal Declaration of Human Rights (UDHR).

However, no legally binding treaties or regulations have been enacted that have established the right of a migrant worker to change employer.

\section{Australia}

Pacific seasonal workers in general have the same workplace rights as national workers. These include wage equality and the right to join unions. Also unions have the right to enter workplaces in order to talk to workers. Further, the unions were involved in the negotiation of the PSWPS.

There is no choice to choose one's employer as the visa of foreign seasonal workers is bound by certain conditions, amongst these is the requirement that the 'holder must not cease to be employed by the employer in relation to which the visa was granted'. Even though workers are bound to one employer, the case is more complex when workers are employed by a labour hire company. In that case the vulnerability of the workers is reduced as the labour hire company is free to place workers on another farm and even in a different region, if the initial grower either goes bankrupt (which has in fact occurred to Tongan workers during the first season of the pilot) or tries to impose abusive working conditions on the migrants.

\section{New Zealand}

Workers in New Zealand can only be hired by recognised employers. Growers, labour hire companies and contractors are eligible to apply for the status of a recognised seasonal employer. Workers were initially bound to one employer; however in August 2008 a government policy change was introduced, allowing workers to move between 
recognised employers, but only with the approval of the Department of Labour and through agreed arrangements with the employers. This change was initiated in order to maximise the workers' earnings as well as to help growers with unexpected down times (Evalue Research, 2010: 82). Further, two growers are eligible to apply together for a Joint Approval to Recruit, thus the workers will first work for one employer and then for the second. In practice, the majority of all workers hired under the RSE scheme still remain with one employer, however the possibility to move between recognised employers has been proven as a suitable risk minimising and income maximising strategy.

Seasonal migrants, as all workers in New Zealand, are allowed to join and participate in union activities. Also the New Zealand Council of Trade Unions was involved in the negotiations that led to the establishment of the Recognised Seasonal Employer scheme, demonstrating a strong emphasis on workers' rights.

\section{France}

In France seasonal workers are allowed to join unions as well as to change employers. According to the French labour code the residence permit of seasonal workers was initially dependent on the working contract of the employer (CODETRAS, 2007: 15). However in 2006 a new law was enacted that introduced a temporary stay permit for seasonal workers granting work rights for six months a year, valid for a total of three years (C. Foreigners, Art. L 313-10, 4). From then on the workers were allowed to also move between employers (Adam and Devillard, 2009: 273).

In 2002 a special union was created to represent the interests of foreign workers in agriculture: The Collectif de Défense des Travailleurs Etrangers Saisonniers dans l'Agriculture (CODETRAS) serves as a forum to document abusive working conditions of seasonal workers and to provide information and legal advice to the migrants. In collaboration with CODETRAS, seasonal workers in the region of Bouches-du-Rhône (southeast France) organised a major strike in 2005 to protest against the non-payment of overtime work and bad housing conditions (Bell, 2005), suggesting strong involvement by the unions in the rights of seasonal workers. In 2011 the French Democratic Confederation of Labour (CFDT), which is a national trade union, launched a nationwide bus tour to raise awareness of the rights of seasonal workers and to provide local consultations. Overall unions in France seem to be strongly interested in protecting the rights of seasonal workers.

\section{Germany}

The general level of workers' rights protection in Germany is ranked among the strongest in the world. The right to freedom of association is guaranteed to all workers by the Basic Law and seasonal workers, as the majority of all workers, are covered by collective bargaining agreements (Puddington, 2010: 24).

The union most involved with foreign seasonal workers is the IG Bau that generally covers workers in agriculture and construction. Seasonal workers are usually tied to their employer for the duration of their residence permit (IG Bauen-Agrar-Umwelt Bundesvorstand, 2005; Bureau of European Policy Advisers, 2010: 46), but the case is different for workers from within the EU as they are not required to obtain a residence permit. Since 1 May 2011 the restriction measures that Germany had applied against the new 2004 accession states of the EU have ceased, allowing Eastern European 
seasonal workers to freely choose their employer. Restrictions on the free movement of workers are currently only applied for Croatian citizens.

Summarising, the right to unionise is granted in all four countries, but the right to choose one's employer is granted to a full extent only in France and New Zealand. However, in Australia labour hire companies and contractors are able to place workers on a different farm (only if workers are not directly employed by the grower) and in Germany Polish workers, who constitute the majority of all foreign seasonal workers, are since 01 May 2011 also able to choose their employer.

\section{Social security rights}

Social security insurances generally protect against a wide range of conditions such as poverty, disability, unemployment and old age. This section will focus on the access of seasonal workers to unemployment and public pension benefits. These two rights were chosen because they are relevant for seasonal workers and have been controversial.

On the one hand, it can be argued that the short-term nature of seasonal work makes retirement and unemployment benefits a marginal issue for seasonal workers. In that case, workers should not be obliged to make mandatory contributions for social services. On the other hand, in countries with a long tradition of foreign seasonal worker employment, such as Germany and France, it is common for workers to return every season, and in some cases they have done this for more than 20 years. Consequently, access to social security is an important issue, especially when considering that agricultural work is often characterised by a high risk of accidents, and that the physically demanding tasks often leave workers unable to work when old or even before reaching the retirement age.

Access to social security protection is important for migrants in order to reduce their vulnerability. As they move between countries and labour markets special provisions in the social security system should ensure that migrants can adequately manage their risks (Sabates-Wheeler, 2009: 3). Thus seasonal workers are particularly interested in being able to access social security rights without long qualifying periods and also in keeping the overall cost for social security low (Organization for Security and Co-operation in Europe, International Organization for Migration, and International Labour Office 2006: 154,157).

International law conventions that deal with the right to social security for migrants are scarce and often remain very general. The most important international obligation has been created by the ICESCR which grants the right for everybody (including migrants) to social security (art 9). However no legally binding specification was made as to what rights can be defined as social security rights or how the problem of portability of rights can be addressed. Nevertheless in General Comment No. 19 'The Right to Social Security' it is specified that seasonal workers also should have access to unemployment benefits.

More specific than international law obligations are provisions created on a regional level by the European Union (EU). The coordination of all social security systems is regulated by the EU and specific regulations have created the right to social benefits portability within the EU. In 2003 these provisions were extended to third country nationals, creating the right to equal treatment with EU nationals (Organization for Security and Co-operation in Europe, International Organization for Migration, and International Labour Office 2006: 156). Thus by EU law all member countries are legally required to grant the same social benefits to nationals as to third country nationals. 


\section{Australia}

All employers are required to pay an additional nine per cent of the employee's salary into the superannuation fund, which is the compulsory Australian public retirement fund, and no exception for seasonal workers applies. However, workers can claim back their superannuation contributions as a lump sum payment upon departure from Australia (Holzmann and Pouget, 2010: 31, 62). The second source of retirement is the age pension, which is a government paid pension that is funded by general taxation. The national pension can only be received after ten years of constant residence in Australia (Holzmann et al., 2005: 10) and is thus unavailable for seasonal workers.

Concerning unemployment benefits Newstart Allowance, the national unemployment scheme for adults, is funded solely by general taxation and is available to Australian citizens or permanent residents only (Centrelink, 2010). Thus, seasonal workers are not eligible for unemployment benefits. However, unemployment benefits are also less relevant for seasonal workers as they are guaranteed a certain number of work hours per week, for a minimum number of months. After the work contract terminates the employer will arrange for the return of the seasonal workers to their home countries. Under these conditions unemployment should consequently not occur during the time period spent in the host country.

In conclusion seasonal workers are obliged to make contributions to the pension fund, which they can claim back at the end of their contract. Although this constitutes an additional effort, workers are still able to reclaim their contribution fees.

\section{New Zealand}

In New Zealand the pension and unemployment benefit schemes are non-contributory schemes that are solely financed by general taxation (Kerr, 1996). Thus, no person in New Zealand is obliged to pay member fees. Seasonal workers contribute to the general taxation scheme but are neither able to access unemployment nor pension benefits (Holzmann and Pouget, 2010: 58) as unemployment benefits are only available for workers who are New Zealand residents or citizens and have continually lived in the country for at least two years. Because of similar requirements seasonal workers are also not eligible for the government paid pension (Work and Income, 2008).

In conclusion, pension and unemployment benefits are unavailable for seasonal workers in New Zealand, but also no wage deductions for these services apply.

\section{Germany}

Generally a foreign seasonal worker in Germany has to make social security contributions if he or she is not insured in the home country. The only exemption applies for short-term employment; if a worker is employed for less than two months or 50 working days a year, than no social security contributions need to be paid, independent of the nationality status.

Unemployment benefits are available for workers who have continually paid member contributions for the last 12 months. As seasonal workers are never employed for 12 months continuously they are not eligible for unemployment benefits (IG Bauen-Agrar-Umwelt Bundesvorstand, 2005: 21; Bureau of European Policy Advisers, 2010: 47).

Contributions to the public pension insurance are mandatory for all seasonal workers who are not insured in their home country. The member fees are 19.5 per cent of the gross salary, which is equally split between employer and worker. The procedure to 
claim back contributions after the termination of the working contract is lengthy, complicated and not always successful. ${ }^{\text {b }}$

Thus, in many cases foreign seasonal workers in Germany have to contribute to the unemployment and retirement fund (if not already insured in their home country), but are not eligible to profit from these services.

\section{France}

All workers in France contribute to the social security system but also benefit from it on exactly the same conditions as nationals (Paparella, 2004: 8; Holzmann and Pouget, 2010: 64). The French national unemployment benefit scheme is financed by member contributions. An income taxation of 6.4 per cent applies. A seasonal worker is eligible for unemployment benefits after having contributed to the scheme for a minimum period of 24 weeks work in the last two years (Holzmann and Pouget, 2010: 64). It is consequently possible for seasonal workers to meet the qualifying period.

Seasonal workers have further access to pension benefits upon certain conditions as laid down in article R.313-2 of the Social Security Code (Code de la Sécurité Sociale. 1995; Paparella, 2004: 19). In certain cases seasonal workers can even qualify for a disability pension or for benefits of the survivor pension (Holzmann and Pouget, 2010: 64).

Once pension benefits are acquired either in France or Germany, seasonal workers are eligible to bring them to their home country if they are EU nationals (such as Poland) or if a bilateral social security agreement is in place. France has concluded agreements of that kind with Tunisia and Morocco, which are home countries of most third country seasonal workers in France (Holzmann and Pouget, 2010: 64).

Overall, seasonal workers in France are, under certain conditions, eligible for both unemployment and retirement pensions upon the same conditions as French nationals. On the face of it France and Germany seem to restrict the social security rights of seasonal workers less than their Pacific counterparts. However, foreign seasonal workers in Germany are often obliged to contribute to the unemployment and retirement scheme without being able to meet the qualifying periods to access these services. The situation is different in France as seasonal workers enjoy total equality with French nationals and at the same time are able to meet the qualifying periods to access these services. However contributions are mandatory without the possibility to opt out.

Table 2 Equality of treatment between foreign seasonal workers and nationals in Australia, New Zealand, Germany and France in relation to work-related rights and social security rights

\begin{tabular}{lllll}
\hline Equality of treatment in the area of: & Australia & New Zealand & Germany & France \\
\hline Work-related rights & $\checkmark$ & $\checkmark$ & $\checkmark$ & $\checkmark$ \\
Right to unionise & $\times ?$ & $\checkmark$ & $\times ?$ & $\checkmark$ \\
Choose one's employer & & & $\checkmark$ & $\checkmark$ \\
$\begin{array}{l}\text { Social Security Rights: } \\
\text { Unemployment benefits }\end{array}$ & $\times$ & $\times$ & $\checkmark$ & $\checkmark$ \\
Retirement benefits & $\checkmark$ & $\times$ & \\
\hline
\end{tabular}


When analysing the differences and similarities of state practice in the four countries it can be concluded that total equality of treatment of foreign seasonal workers with domestic workers in all analysed categories is only met by France. But also none of the four countries discriminate in all analysed areas, resulting in a rather complex picture of different level of rights.

Table 2 summarises in which categories each of the four countries provide equal treatment for foreign seasonal workers.

\section{Developing best practice}

This section analyses the difference between state practice and best practice. As has been shown above international law obligations do permit a certain level of discrimination and national states comply with these obligations by treating seasonal workers equally in some areas while discriminating against them in others.

It is first necessary to establish sources of best practice. For the purpose of this analysis treaties that have not been widely ratified, treaties that have been signed but are not yet in force as well as sources of soft law have been chosen to reflect elements of best practice with regards to the rights of seasonal workers. Treaties, conventions and regulations that are widely ratified often only constitute the lowest level of common interest that can be agreed upon and can thus be considered as ensuring a minimum standard of protection. In order to define best practice it seems to be more promising to turn to provisions that have not been widely ratified and elements of soft law, which are not legally binding. These provisions are more likely to contain encompassing social protection rights for workers that address their specific needs and should thus be considered as benchmark provisions.

One of the most relevant non-binding provisions is the ILO multilateral framework on labour migration. Further sources of best practice that will be analysed are relevant ILO conventions, applicable UN recommendations, articles of the UDHR and articles of the ICRMW.

The majority of the provisions focus on the general right of non-discrimination. However, contrary to their widely ratified counterparts, these provisions specify the areas of equal treatment. For example Art 6(1) of the Convention concerning Migration for Employment (ILO Convention No. 97) states that equal treatment must be granted in relation to working conditions, trade union membership, accommodation, social security and employment taxes (Ryszard Cholewinski, 2005). Additionally under Art 59(1) the ICRMW grants seasonal workers a set of specific rights, amongst these the right to freedom of movement in the host country (including the freedom to choose one's residency). Most importantly the convention states that seasonal workers should enjoy equality of treatment with nationals in relation to unemployment benefits, protection against dismissal, and the access to social and health services (Art 54(1)). Similar provisions can be found in the EU directive regulating the Common Entry and Residence Conditions for Third-Country Seasonal Workers (Directive of the European Parliament and of the Council, 2014).

This article will now examine in detail what specific recommendations were made in the previously analysed rights sets. 


\section{Work-related rights}

The United Nations has created a separate body, the International Labour Organization (ILO), which develops and oversees international labour standards with the aim of promoting decent work conditions. Its 'tripartite' structure, which brings together employers, workers and government representatives, is its main characteristic. In that respect ILO Conventions can be considered as indicators for best practice.

The ILO multilateral framework on labour migration as well as other conventions dealing with labour rights for migrants have strongly focused on the right for all workers (including migrants) to join and participate in union activities (ILO Conventions No. 87, No. 97 and No. 98; ICRMW and UDHR).

The right to free choice of employment is guaranteed under the UDHR and the ICRMW, as well as by the EU directive on the Conditions of Entry and Stay of Third-Country Nationals for the Purpose of Employment as Seasonal Workers (Directive of the European Parliament and of the Council, 2014). However, certain restrictions apply, for example the host state is allowed to restrict access to certain categories of employment only. The ICRMW further recommends that all workers should enjoy freedom of movement in the state of employment.

While it is recommended by several international instruments to grant migrants the right to change their employer, two out of the four analysed case countries do not fully comply with this recommendation. ${ }^{3}$ However the cases of New Zealand and France demonstrate that a change of policy is possible and works for the benefit of the workers, without impeding the functioning of the whole scheme. A best practice model for social protection rights of foreign seasonal workers should thus also encompass the right to freely choose one's employer as well as the right to unionise.

\section{Social security rights}

The right to social security for everybody, including migrants has been confirmed by several conventions such as the UDHR. More specific recommendations include the right of migrants to have access to pension benefits (General Comment 19 of the UN Committee on Economic, Social and Cultural Rights) as well as equal treatment with nationals concerning social security benefits (ILO Conventions No. 118, No. 97 and No. 143 and the EU directive concerning seasonal workers (Directive of the European Parliament and of the Council, 2014). The only international convention that has established the right to maintain acquired social security rights for migrants is the 1982 Convention on the Maintenance of Social Security Rights (ILO Convention No. 157), which was ratified by only four countries and is thus considered as highly unsuccessful.

Even though international and regional provisions have created a right for migrants to access social benefits, most of the obligations remain rather general without specifying for example which exact social security rights should be made available to migrants and under what conditions.

For the four analysed countries the following considerations should be taken into account: In France and Germany retirement and unemployment benefits are largely financed through member contributions and seasonal workers are obliged to contribute to the system without being able to access it in many cases as their short-term contracts hinder them from fulfilling the qualifying periods. In New Zealand and Australia where the majority of workers are young and not engaged with the scheme for many years retirement benefits 
seem to be redundant, in particular when considering that the sending countries do not have any social security system the acquired benefits could be incorporated into. The case is similar with unemployment benefits as employers are obliged to guarantee a certain amount of hours of work per week, thus unemployment should not occur at all.

In this context unemployment and retirement schemes seem to either create an unprofitable financial burden for seasonal workers or are simply unnecessary or not applicable for them. In consequence, a model of best practice should enable migrants to meet the qualifying periods in order to profit from social security rights, make the contributions optional, or create different ways of social security protection, for example through separate insurance coverage.

\section{Results, Discussions and Conclusions}

In summary, all analysed principles promote equality of treatment between seasonal workers and nationals. However most of these provisions are only slightly more specific than their widely ratified counterparts. In that respect it is suggested that there is more to the argument than simply promoting equality. Seasonal workers are not in exactly the same position as nationals, so that the quest for equal treatment is trying to treat two things equally when in fact both may have different needs. The different position of seasonal workers arises due to their remote connection with the host country and their legal status dependent on a temporary visa. A best practice model for social protection rights should consequently have a stronger focus on equity as opposed to equality. It is thus necessary to review legislation to increase the eligibility of migrants to access social security benefits or to provide specific benefits for migrant workers, as has been implemented by the Canadian seasonal worker scheme (Van Ginneken, 2013: 213, 218).

The analysis of social protection rights for foreign seasonal workers across Australia, New Zealand, France and Germany leads to the following conclusion: In the case of work-related rights, especially the right to unionise and the right to freely choose one's employer, the doctrine of equal treatment seems to be appropriate as these rights concern the working conditions and rights at one's workplace which should be the same irrespective of nationality or visa status. Whereas it seems understandable that countries restrict the sector of employment (for example to only horticulture or viticulture), workers should be free to choose their employer within that sector and organise themselves in unions. Concerning social security rights however equal treatment with nationals creates an obligation to pay contribution fees without in most cases being covered by these services. Thus, in order to reflect the specific needs of foreign seasonal workers, three options should be considered: Shortening the qualifying periods, making social security contributions optional or, as an alternative to the mandatory public coverage, offering separate insurance targeting the specific needs of these workers.

The comparison of seasonal worker regulations across four countries has revealed several similarities and differences. All four countries grant their foreign seasonal workers the right to unionise. With the exception of New Zealand all countries also provide access to retirement benefits. However, the majority of foreign seasonal workers in Germany and Australia will be unable to meet the qualifying periods. Differences were detected in the area of unemployment benefits. While seasonal workers in 
Australia and New Zealand are not allowed to access unemployment benefits, they are eligible for those services in Germany and France. The major difference this four country comparison has revealed is the fact that Germany and France aim to treat their foreign seasonal workers equally to domestic workers, while Australia and New Zealand provide specific rights for their agricultural migrants. Additional protection for seasonal workers is offered within and outside the national framework of both of these countries. In New Zealand for example all foreign seasonal workers are covered by accident compensation, as this protection applies for everyone within the country. Moreover employers in Australia and New Zealand are obliged to provide a specific protection for foreign seasonal workers, labelled as pastoral care. These obligations include providing suitable accommodation, necessary language translation, access to personal banking and an induction program. Pastoral care obligations in these two countries have been a successful way in protecting foreign workers and reducing their vulnerability. Also workers in all four countries are covered by mandatory health insurance.

The four country comparison has thus strengthened the conclusion of this paper that the 'more rights the better' does not per se constitute the most suitable approach, as foreign seasonal workers have very specific needs and thus require customised protection. In some cases, as for example in relation to social security, solutions that specifically target the needs of foreign seasonal workers need to be established. However in most other cases the equal treatment doctrine of foreign seasonal workers and nationals of the host country constitutes the most suitable approach in creating appropriate level of social protection rights that best meets the interests of all stakeholders.

\section{Endnotes}

${ }^{a}$ The New Zealand RSE scheme started on 1 April 2007, consequently the number for the first year does not cover the complete season.

${ }^{\mathrm{b}}$ According to the German Pension Fund (www.deutsche-rentenversicherung.de) foreign workers are obliged to fulfil certain criteria before being able to claim back contributions. Amongst these are a waiting period of 24 months. Further the worker needs to prove that he or she is not eligible or obliged for membership in the German retirement fund. Nevertheless each case underlies an individual examination.

${ }^{c}$ In Germany only seasonal workers from EU countries where no restriction measures are in place (for example Polish workers) are free to choose their employer. For all other foreign seasonal workers the right to freely choose one's employer is not granted.

Competing interests

The authors declare that they have no competing interests.

Authors' information

Dr. Christine Brickenstein has just completed her PhD at Macquarie University in Sydney as well as at the Institute for Migration Research and Intercultural Studies (IMIS) at Osnabrück University in Germany. Her research interests focus on temporary low skilled migration, with a particular focus on foreign seasonal workers in Oceania and Europe.

\section{Acknowledgements}

I would like to express my gratitude to Professor Brian Opeskin and Associate Professor Fei Guo from Macquarie University, as well as Professor Jochen Oltmer from Osnabrück University. Their intensive guidance and suggestions were invaluable for the preparation of this article. The writing of this paper was supported by an International Macquarie University Research Excellence Scholarship. 


\section{References}

Adam, C, \& Devillard, A. (2009). Comparative Study of the Laws in the 27 EU Member States for Legal Immigration Including an Assessment of the Conditions and Formalities Imposed by Each Member State for Newcomers. Geneva: European Parliament, IOM.

Anderson, B. (2008). Migrants and Work-related Rights. Ethics and International Affairs, 22(2), 199-203.

Appleyard, R., \& Stahl, C. W. (1995). South Pacific Migration: New Zealand Experience and Implications for Australia. Canberra: Australian Agency for International Development.

Avato, J, Koettl, J, \& Sabates-Wheeler, R. (2010). Social Security Regimes, Global Estimates, and Good Practices: The Status of Social Protection for International Migrants. World Development, 38(4), 455-466.

Becker, J, \& Heller, W. (2002). Polnische Saisonarbeiter in der Bundesrepublik Deutschland. Politische und Ökonomische Bedingungen eines Spezifischen Temporären Arbeitsmigrationssystems [Polish seasonal workers in the Federal Republic of Germany. Political and economic conditions of a specific temporary labor migration system. Berichte zur Deutschen Landeskunde, 76(1), 71-87.

Bell, N. (2005). Grève des Saisonniers Agricoles OMI dans les Bouches du Rhone [foreign agricultural seasonal worker strike in the region Bouches du Rhone]. Retrieved from http://www.millebabords.org/spip.php?article2784.

Bennett, P., \& Woodhouse, M. (2014). Boost for Horticulture and Viticulture Industry. [Press Release 22.07.2014]. Retrieved from http://beehive.govt.nz/release/boost-horticulture-and-viticulture-industry.

Bundesagentur für Arbeit. (2010). Zulassungen für Osteuropäische Saisonarbeitnehmer zum Deutschen Arbeitsmarkt [Eastern European seasonal workers admissions to the German labor market] 2010 (Jan-Nov) - 2001: Gesamt und Landwirtschaft (LW), ZAV-Arbeitsmarktzulassung. Bonn: Bundesagentur für Arbeit.

Bureau of European Policy Advisers. (2010). Opening Europe's Doors to Unskilled and Low-skilled Workers: A Practical Handbook. In S. Bertozzi (Ed.): European Union.

Carens, JH. (2008). Live-in Domestics, Seasonal Workers and Others Hard to Locate on the Map of Democracy. Journal of Political Philosophy, 16(4), 419-445.

Castles, S. (2006). Guestworkers in Europe: A Resurrection? International Migration Review, 40(4), 741-766.

Centrelink. (2010). Newstart Allowance: Residence Requirements. Retrieved from http://www.centrelink.gov.au/internet/ internet.nsf/payments/newstart_residence.htm.

Cholewinski, R. (2005). Protecting Migrant Workers in a Globalized World. Washington DC: Migration Policy Institute.

Cholewinski, R, De Guchteneire, P, \& Pécoud, A (Eds.). (2009). Migration and Human Rights: the United Nations Convention on Migrant Workers' Rights. Paris: UNESCO Publishing.

CODETRAS. (2007). Travailleurs étrangers « Saisonniers » de longue Durée [long-term foreign seasonal workers]. Marseille: Collectif de Defense des Travailleurs Etrangers Dans L'Agriculture.

De Lary, H. (2004). Bilateral Labour Agreements Concluded by France. In Organisation for Economic Co-operation and Development (Ed.), Migration for Employment: Bilateral Agreements at a Crossroads (pp. 43-54). Paris: OECD.

Deutsches Bundesamt für Migration und Flüchtlinge. (2010). Migrationsbericht 2008 [migration report 2008] (Vol. 62). Bern-Wabern: BAMF.

Directive of the European Parliament and of the Council. (2014). On the Conditions of Entry and Stay of Third-Country Nationals for the Purpose of Employment as Seasonal Workers PE-Cons 113/13 (Vol. 07.02.2014).

European Migration Network. (2010). Ad-Hoc Query on Seasonal Workers and Intra-Corporate Transferees (ICTs) Requested by Commission EMN NCP on 17th March 2010

Evalue Research. (2010). Final Evaluation Report of the Recognised Seasonal Employer Policy (2007-2009). Wellington: Report to the New Zealand Department of Labour.

Evans, C. (2010). Australia's Horticulture Industry to Benefit from Adjustments to the Pacific Seasonal Worker Pilot Scheme [Media Release]. Minister for Tertiary Education, Skills, Jobs and Workplace Relations. Retrieved from http://www.driedfruitsaustralia.org.au/news.php?id=495.

Code de la Sécurité Sociale. (1995). Partie Réglementaire - Décrets en Conseil d'Etat [Social Security Code: Regulatory Part-Orders of the Council of State].

Gibson, J., \& McKenzie, D. (2010). The Development Impact of New Zealand's RSE Seasonal Worker Policy: University of Waikato, World Bank.

Gibson, J, McKenzie, D, \& Rohorua, H. (2008). How Pro-poor is the Selection of Seasonal Migrant Workers from Tonga under New Zealand's Recognised Seasonal Employer Program? Pacific Economic Bulletin, 23(3), 187-204.

Gibson, J, McKenzie, D, \& Rohorua, H. (2013). Development Impacts of Seasonal and Temporary Migration: A Review of Evidence from the Pacific and Southeast Asia Discussion Paper Series CDP No 08/13. University College London: Centre for Research and Analysis of Migration.

Hay, D, \& Howes, S. (2012). Australia's Pacific Seasonal Worker Pilot Scheme: Why Has Take-up Been so Low? Development Policy Centre Discussion Paper 17. Canberra: Crawford School of Public Policy, The Australian National University.

Holzmann, R., Koettl, J., \& Chernetsky, T. (2005). Portability Regimes of Pension and Health Care Benefits for International Migrants: An Analysis of Issues and Good Practices SP Discussion Paper No 0519. Washington, DC: World Bank.

Holzmann, R, \& Pouget, Y. (2010). Social Protection for Temporary Migrant Workers: Conceptual Framework, Country Inventory, Assessment and Guidance A Study prepared for the Global Forum of Migration and Development. Marseille: World Bank and Marseille Center for Mediterranean Integration.

IG Bauen-Agrar-Umwelt Bundesvorstand. (2005). Netzwerk Soziales Europa: Informationen für Saisonarbeitskräfte in Deutschland [Network Social Europe: Information for seasonal workers in Germany]. Berlin: IG Bauen-Agrar-Umwelt.

International Labour Office. (2010). International Labour Migration: A Rights-based Approach. Geneva: International Labour Organisation.

Kerr, KB. (1996). Unemployment Compensation Systems and Reforms in Selected OECD Countries. Ottawa: Library of Parliament, Research Branch, Organisation for Economic Co-operation Development.

Lamarche, L. (2014). Human Rights, Social Security and Migrant Workers. In R Blanpain (Ed.), Social Security and Migrant Workers: Selected Studies of Cross-Border Social Security Mechanisms (Vol. Bulletin of Comparative Labour Relations, pp. 9-30). Alphen aan den Rijn: Kluwer Law International. 
MacDermott, T, \& Opeskin, B. (2010). Regulating Pacific Seasonal Labour in Australia. Pacific Affairs, 83(2), 283-305. Maclellan, N. (2008). Workers for All Seasons? Issues from New Zealand's Recognised Seasonal Employer (RSE) Program. Hawthorn: Institute for Social Research, Swinburne University of Technology.

Martin, P. (2003). Managing Labour Migration: Temporary Worker Programs for the 21st Century. Geneva: International Institute for Labour Studies.

Martin, P. (2007). Towards Effective Temporary Worker Programs: Issues and Challenges in Industrial Countries International Migration Papers (Vol. 89). Geneva: International Labour Organization.

McKenzie, D., \& Gibson, J. (2010). The Development Impact of a Best Practice Seasonal Worker Policy Policy Research Working Paper 5488: The World Bank: Development Research Group http://www.wds.worldbank.org/external/ default/WDSContentServer/WDSP/B/2010/11/30/000158349_20101130131212/Rendered/PDF/WPS5488.pdf.

New Zealand Department of Labour. (2011). RSE Workers Arrival into New Zealand - RSE Financial Year 2009/2010.

Okolski, M. (2004). Seasonal Labour Migration in the Light of the German-Polish Bilateral Agreement. In OECD (Ed.), Migration for Employment: Bilateral Agreements at a Crossroads (pp. 203-214). Paris Cedex: OECD Publishing.

Olivier, M. (2011). Political and Regulatory Dimensions of Access, Portability and Exclusion: Social Security for Migrants, with an Emphasis on Migrants in Southern Africa. In R Sabates-Wheeler \& R Feldman (Eds.), Migration and Social Protection: Claiming Social Rights beyond Borders (pp. 117-139). Hampshire: Palgrave Macmillan.

Organization for Security and Co-operation in Europe, International Organization for Migration, \& International Labour Office. (2006). Handbook on Establishing Effective Labour Migration Policies in Countries of Origin and Destination. Vienna and Geneva: OSCE, IOM and ILO.

Paparella, D. (2004). Social Security Coverage for Migrants: Critical Aspects. Paper presented at the European Regional Meeting: Migrants and Social Protection, Oslo. http://www.issa.int/pdf/oslo04/2paparella.pdf.

Plewa, P. (2010). The Politics of Seasonal Foreign Worker Admissions to France, 1974-2010 EUI Working Paper RSCAS 2010/63. Florence: European University Institute.

Puddington, A. (2010). The Global State of Workers' Rights: Free Labor in a Hostile World: Freedom House.

Ramasamy, S, Krishnan, V, Bedford, R, \& Bedford, C. (2008). The Recognised Seasonal Employer Policy: Seeking the Elusive Triple Wins for Development through International Migration. Pacific Economic Bulletin, 23(3), 171-186.

Reed, C, Southwell, A, Stafford, N, Healy, M, \& Barker, B. (2010). Interim Evaluation of the Pacific Seasonal Worker Pilot Scheme: Executive Summary Prepared for: Department of Education, Employment and Workplace Relations: TNS social research.

Rihoux, B, \& Ragin, CC (Eds.). (2008). Configurational Comparative Methods: Qualitative Comparative Analysis and Related Techniques. Los Angeles: Sage Publications.

Rosario, T. (2008). Best Practices in Social Insurance for Migrant Workers: The Case of Sri Lanka. ILO Asian Regional Programme on Governance of Labour Migration, Working Paper 12.

Ruhs, M, \& Martin, P. (2008). Numbers vs. Rights: Trade-Offs and Guest Worker Programs. International Migration Review, $42(1), 249-265$.

Sabates-Wheeler, R. (2009). Extending Social Security Coverage: Good Practices, Lessons learnt and Ways Forward ISSA Working Paper No 12. Geneva: International Social Security Association.

Van Ginneken, W. (2013). Social Protection For Migrant Workers: National and International Policy Challenges. European Journal of Social Security, 15(2), 209-221.

Weissbrodt, D. (2008). The Human Rights of Non-Citizens. Oxford: Oxford University Press.

Work and Income. (2008). New Zealand Superannuation Overview. Retrieved from http://www.workandincome.govt.nz/ individuals/65-years-or-older/superannuation/superanuation-overview.html.

\section{Submit your manuscript to a SpringerOpen ${ }^{\circ}$ journal and benefit from:}

- Convenient online submission

- Rigorous peer review

- Immediate publication on acceptance

- Open access: articles freely available online

- High visibility within the field

- Retaining the copyright to your article 